\title{
SUCCESS AND FAILURE ALONG THE MODDER RIVER DURING THE ANGLO-BOER WAR: THE INFLUENCE OF TERRAIN
}

\author{
HAP Smit and HS Janse van Rensburg \\ Stellenbosch University
}

\begin{abstract}
The influence of terrain ${ }^{1}$ on military operations is a well-known and wellresearched topic. In a South African context, the body of literature about this topic is, however, not as well developed. This article strives to make a contribution to literature about South African battles and the influence of terrain on the outcome of such battles. During the Anglo Boer War (1899-1902), two important battles were fought along the Modder River. The first of these battles is known as the Battle of Modder River or Twee Riviere (Two Rivers, if directly translated from Afrikaans), while the other is known as the Battle of Paardeberg. ${ }^{2}$ These battles were fought in close proximity to one another, both in distance and time. The terrain of the battlefields played a key role in both engagements. This article suggests that the spatial arrangement of the koppies (hills) and the fact that they were much closer to the Boer laager at Paardeberg than at the battle of Modder River played a key role in Cronje's surrender to the British.
\end{abstract}

\section{Introduction}

The article starts with a brief overview of the literature on terrain and battles, and then discusses the opening battles of the Anglo-Boer War, up to the Battle of Modder River. Thereafter, the Battle of Modder River will be discussed with emphasis on the terrain of the battlefield and its influence on the outcome of the battle. The events between the battles at Modder River and Paardeberg will then be briefly outlined, after which the Battle of Paardeberg will be discussed, again

Scientia Militaria, South African Journal of Military Studies, Vol 42, Nr 2, 2014, pp. 117-142. doi : $10.5787 / 42-2-1096$ emphasising the influence of the terrain of the battlefield. Lastly, a comparison between the terrains of the battle sites is made, and the effect of the differences in terrain on the battles is noted. 


\section{The influence of terrain on military campaigns}

In the preface to their book, Modern military geography, Galgano and Palka state, "factors of geography have had a compelling influence on battles and campaigns throughout history". ${ }^{3}$ Even a cursory study of the available literature will affirm this statement. Since the earliest times, the influence of geography on battles has been well known and thoroughly researched, with the result that a large body of knowledge exists regarding the influence of geographical factors such as climate, weather and terrain on battles. Unfortunately, the mere existence of such a body of knowledge does not automatically mean that these factors are always adequately taken into consideration during the planning and execution of a battle or campaign. Two notable examples of the effects of an inadequate understanding and appreciation of the influence of climate and terrain on military operations can be found in the Russian campaigns of both Napoleon and Hitler. ${ }^{4}$ Innumerable other examples exist.

In the literature, the influence of geographical factors on battles has been recorded by authors such as -

- Davies (1946) - who analysed the geographical factors that played a role in the invasion and battle of Normandy;

- Ackermann (1957) - with a PhD thesis in Geography on the influence of geography during the Anglo-Boer War; ${ }^{5}$

- $\quad$ Puckett (1992) - on the Rapido River crossings during the Second World War; ${ }^{6}$

- Gray (1999) - on "inescapable geography";

- Palka, Galgano and Corson (2005) - who gave a military geographic perspective on Operation Iraqi Freedom; ${ }^{8}$

- Palka (2005) - on the military geographic challenges during Operation Enduring Freedom in Afghanistan; ${ }^{9}$

- Hausler (2006) - who discussed historic maps for terrain evaluation; ${ }^{10}$

- Schroeder (2011) - on mountainous terrain and the Prussian invasions of Bohemia in 1757 and $1866 ;^{11}$

- Gnaser (2011 - who wrote on the warfare in mountainous regions in the Semmering area in Austria during the last days of the Second World War; ${ }^{12}$ and

- Galgano (2011) - on streams and the military landscape, ${ }^{13}$ and the geography of amphibious warfare. ${ }^{14}$

Add to this the seminal work by Winters, Galloway, Reynolds and Rhyne on the influence of weather and terrain in the conduct of war, ${ }^{15}$ Collins' Military geography for professionals and the public, ${ }^{16}$ and Galgano and Palka's 2011 
Modern military geography, ${ }^{17}$ and it is abundantly clear that much has been written on this aspect of military geoscientific enquiry.

A recurring theme in the literature on geographical factors in military operations is the influence of terrain on the battles discussed. Since the early 1990s, authors, such as

- Metzger (1992) - "Terrain analysis for Desert Storm"; 18

- $\quad$ Doyle and Bennet (1997) - "Military geography: Terrain evaluation and the British Western Front 1914-1918"; 19

- Doyle and Bennet (1999) - "Military geography: The influence of terrain in the outcome of the Gallipoli Campaign, 1915"; ${ }^{20}$

- Tate (2006) - "Terrain analysis for Decision Making"; ${ }^{21}$

- Kimble and O'Sullivan (2010) - "Terrain and guerrilla warfare in Navarre, 1808-1814",22

- $\quad$ Ehlen and Abrahart (2010) - Effective use of terrain in the American Civil War: The Battle of Fredericksburg, December 1862"; ${ }^{23}$ and

- Doyle (2011) - Terrain evaluation of the Hannibalic Alpine Invasion Route" 24

all made significant contributions in this regard. However, they represent only a small selection of authors who deal with this aspect of geographical battle analysis.

As indicated above, a large corpus of international literature on the influence of terrain on military operations exists. In a South African context, this is not the case. Many important battles fought on South African soil have not yet been subjected to scrutiny by military geoscientists, and consequently have not been specifically evaluated in terms of the influence of terrain on the outcome of those battles. Recently, authors such as Smit $(2011)^{25}$ and Dye $(2012)^{26}$ have started to add to the sparse South African literature on this aspect of South African battles.

This article is an attempt to develop the literature available on the influence of terrain on battles in a South African context further.

\section{The Anglo-Boer War (1899-1902): The start of hostilities}

On 9 October 1899, the Zuid-Afrikaansche Republiek (ZAR), with Paul Kruger as president, issued Britain with an ultimatum that would eventually lead to war. $^{27}$

The ultimatum demanded that all British troops be withdrawn from the Transvaal's borders, that all British troops that had arrived since 1 June 1899 be withdrawn from Southern Africa, and that British troops on the high seas bound for Southern Africa be sent back. Failure to comply with these demands would be 
considered a declaration of war by the two Boer Republics. ${ }^{28}$ At five o'clock on the afternoon of Wednesday, 11 October 1899, the ultimatum expired without any response from Britain. As a result, the two Boer Republics, the ZAR and the Orange Free State, bound by a treaty to help each other in the event of war, went on the offensive. ${ }^{29}$.

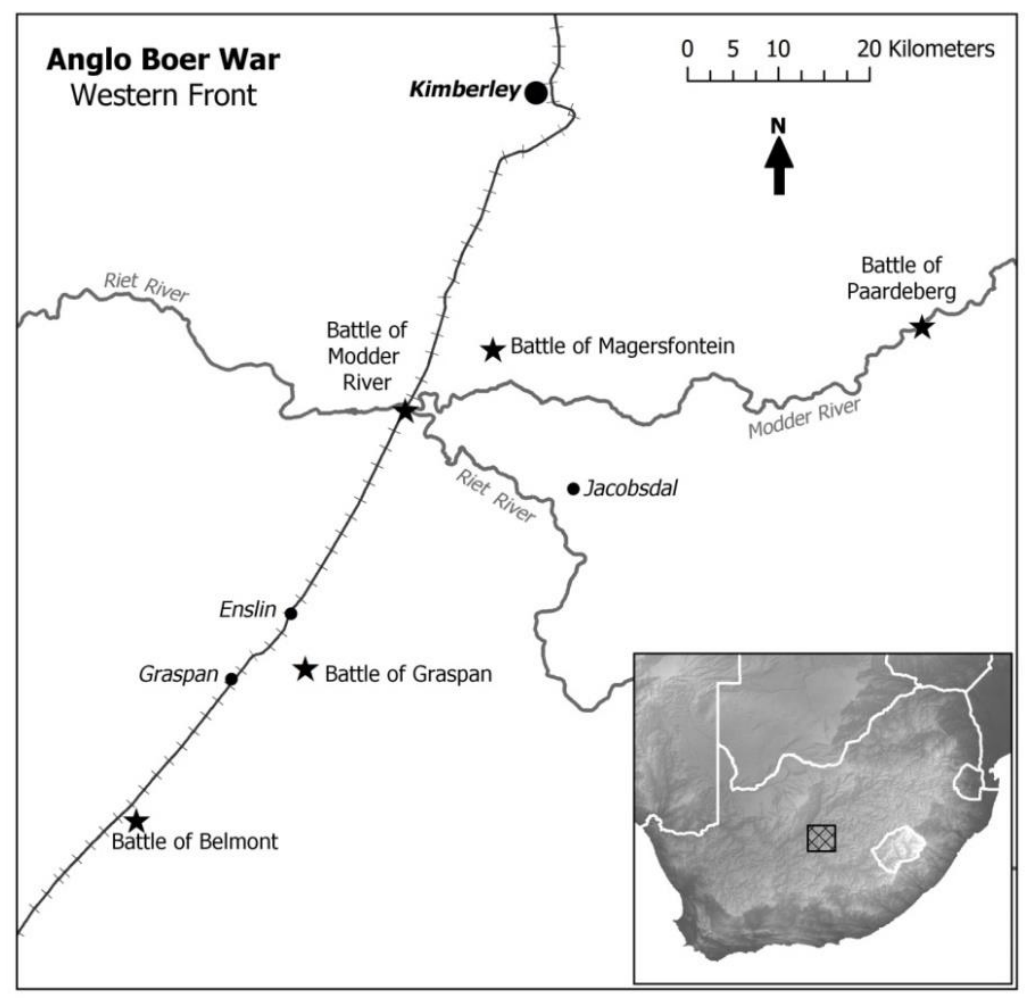

Figure 1: Anglo-Boer War western front (Map produced by TJ Flügel)

The first few weeks of the war brought a reality check for the British Army. The Boer armies invaded the British colony of Natal and encircled Sir George White and 14500 men in Ladysmith. ${ }^{30}$ On the western front, the important towns of Mafeking and Kimberley were besieged and other, smaller towns attacked and taken. ${ }^{31}$ On 31 October, General Buller arrived in the Cape Colony on board the Dunottar Castle. As supreme commander of the British forces in South Africa, he had devised a simple strategy. He would transport his 46000 men, 114 cannons and 
47 machine guns by rail to the north-eastern Cape front and launch a direct assault against the Free State and then against the ZAR.

The changed military situation forced him to rethink his strategy. Kimberley, the second largest city in the Cape Colony, was surrounded by Boer forces, while General White and his 14500 men were trapped in Ladysmith, on the Natal front. Buller devised a new strategy. He would send Lieutenant General Paul Sanford Methuen, 3rd Baron Methuen, with 15000 men to relieve Kimberley, while he himself would take 21600 men to rescue General White in Ladysmith. ${ }^{32}$ Two smaller contingents, 4300 men under Lieutenant General Gatacre, and 5000 men under Major General French, would reinforce British forces in the vicinity of Colesberg and Stormberg respectively, to stall the Boer advance on these two fronts. $^{33}$

The opening battle of Methuen's campaign occurred at Belmont on 23 November 1899. General Prinsloo, with approximately 2000 Boer soldiers under his command, took up position in the ridges east of Belmont station (see Figure 1). ${ }^{34}$ After a brief but intense battle, the Boers, unaccustomed to artillery bombardment, had had enough and they fled from the ridge by 10:00, allowing the British to continue their march to Kimberley the next day. ${ }^{35}$

Two days later, on 25 November 1899, it was General De la Rey's turn to try and stop the British march to Kimberley. He positioned his 2000 Boer troops in the koppies on both sides of the railway line between the two small railway stations of Graspan and Enslin. The attacking British soldiers suffered under the hot African sun, but once again Methuen used his overwhelming force to win an easy battle by attacking the Boer positions in the koppies and forcing them to retreat. ${ }^{36}$ During the battles of Graspan and Enslin, Methuen used the conventional tactics of the time, a heavy artillery bombardment of the enemy position followed by a frontal infantry attack to dislodge the enemy from their positions. The Boers also followed conventional doctrine: dominate the high ground. After this battle, the Boers realised that domination of the high ground was not working in their favour, and they decided to engage the British from an entrenched position along the Modder River. The importance of this change in tactics was not fully appreciated by Methuen.

\section{The Battle of Modder River (28 November 1899)}

The next geographic obstacle Methuen had to overcome on his way to Kimberley was the Modder River. He had to cross the Modder River just west of its confluence with the Riet River because the railroad to Kimberley bridged the river at that point. The Boers had destroyed the railway bridge, but Methuen planned to rebuild it before continuing to Kimberley. He had to rely on the railroad to provide 
him with everything from food and ammunition to medical supplies. In a country without proper roads to transport a large army, it would have been foolish to leave this lifeline, even if only for a short time. ${ }^{37}$

The historian LS Amery is of the opinion that General Koos de la Rey made the correct military assessment of the two previous Boer defeats. He realised that using the steep koppies that the Boers had selected as defensive positions at both Belmont and Graspan, was neither a good defensive strategy, nor tactically sound, but that it actually invited defeat. In the exceedingly flat terrain of the Northern Cape, the isolated koppies stood out prominently and formed an ideal target for Methuen's artillery. Once the British soldiers reached the base of the koppies, they were in dead ground and could not be seen from the top of the koppies, making it possible for them to regroup under cover before launching an attack against the Boer positions on top of the koppies. The effectiveness of the British artillery bombardment was also increased by the rocky terrain of the koppies, as shrapnel ricocheting off rocks led to more Boer casualties. ${ }^{38}$ Consequently, the Boers abandoned the koppies for positions on the banks of the Riet and Modder Rivers. ${ }^{39}$

The high river banks and the soft alluvial soil of the Riet and Modder Rivers made this an ideal defensive position. Because they were tied to the railroad, the British had to attack over a flat, almost featureless plain which formed an almost perfect field of fire. The fact that the people of Kimberley used this area from time to time for horseracing testifies to the evenness of the terrain. ${ }^{40}$

The Boers entrenched themselves on both sides of the railroad to Kimberley, from the small village of Rosmead for about five miles (8,05 kilometres) eastwards. Immediately to the east of the railroad, the Modder and Riet Rivers joined and continued west as the Riet River. The river beds of the Riet and Modder Rivers made for excellent defensive positions (see Figure 2). In the first place, they were so deep that from the plain surrounding the river, the trees in the river bed and the river itself were invisible to an attacking force. On each side of the river, which flowed more or less in the middle of the bed, the terrain sloped gently for between 20 and 200 paces to a vertical river bank that was 1,5 to 3 metres high and had to be scaled to reach the plain, 7 to 9 metres above the water. Behind this natural trench, defenders could stand and fire at will at attackers who would not be able to see them. ${ }^{41}$ Under normal conditions, the river was nine to 15 paces wide, but due to good summer rains, it had swelled to about 30 paces. The river was deep, with thick mud at the bottom, making it almost impossible to cross, except at certain drifts, which were well known to the Boers. This already excellent position was further strengthened by the Boers digging and concealing trenches on the plain just south of 
the Modder and Riet Rivers, as well as by removing any bushes that could possibly hinder their line of sight or impede their line of fire. ${ }^{42}$

As the Boers kept a possible retreat in mind, and because the river could only be crossed at the drifts, they deployed some soldiers as well as all their cannons on the north banks of the Riet and Modder Rivers, as well as in the area between the Riet and Modder Rivers. ${ }^{43}$ Some snipers climbed trees growing on the north banks to get a better view across the river. ${ }^{44}$

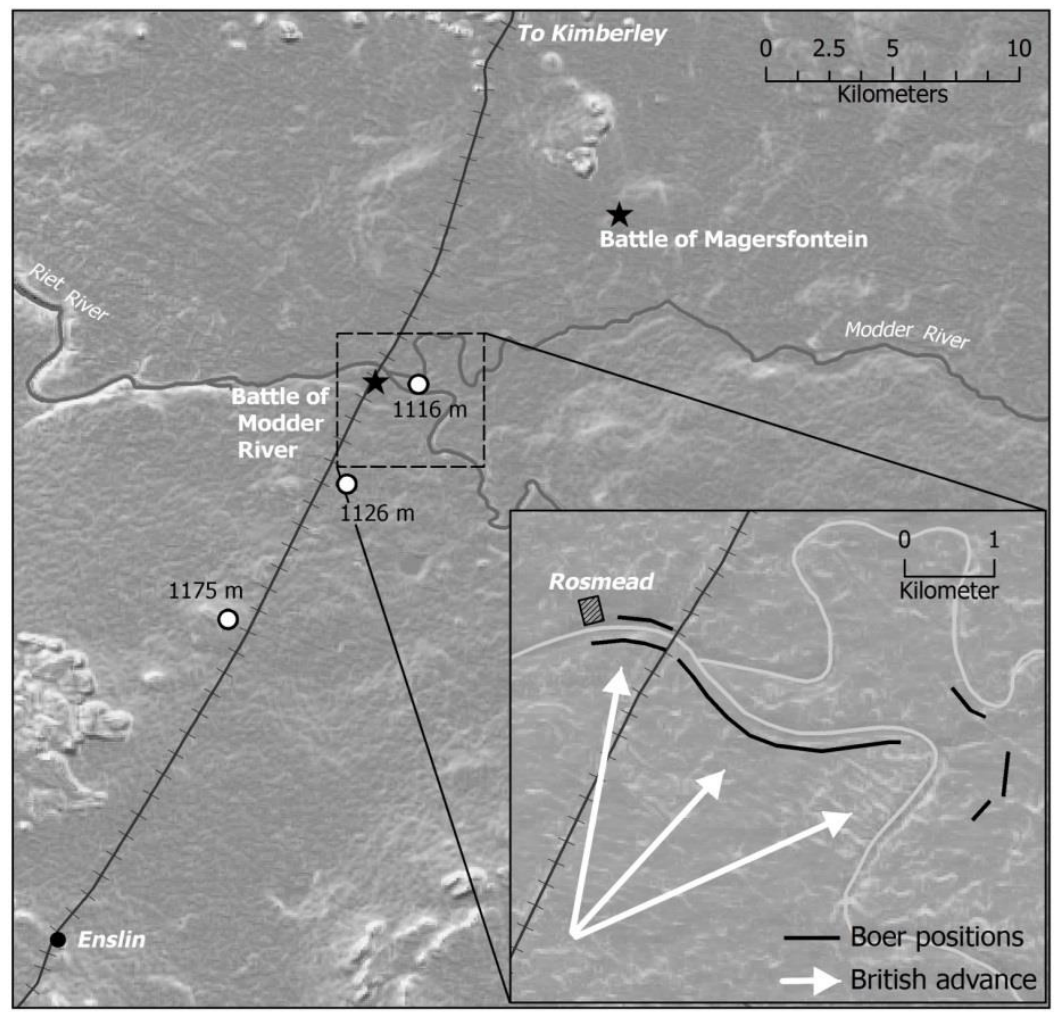

Figure 2: Battle of Modder River ${ }^{45}$

A total of 2200 Boer soldiers, supported by five or six cannons and four pom-poms, ${ }^{46}$ waited in this position for Methuen's force which had to launch a frontal attack over a flat plain that was almost totally devoid of cover. ${ }^{47}$ To compound the British difficulty, Methuen failed to conduct a good reconnaissance of the area south of the Modder River station, as the open terrain made it extremely 
difficult to do so. The excellent marksmanship of the Boers and the smokeless ammunition they used enabled them to pick off British scouts over long distances without giving away their own positions. According to Pakenham, Methuen complained about the maps he had available, claiming that they were "of little value" and that the information he could obtain was of "even less value, as the open country, plus Mauser rifles render reconnaissance all but impossible". ${ }^{4}$ Two vitally important pieces of geographic information that Methuen therefore missed were that the Riet River swung sharply to the south on the extreme eastern limit of the Boer positions, and that the Boers also occupied positions along the Riet River.

Methuen had at his disposal only a sketch map of the Modder River in the immediate vicinity of the bridge over the river. This was hopelessly inadequate and he did not deem it necessary to do further reconnaissance to explore the exact course of the river before ordering his troops into battle shortly after 04:00 on 28 November. For this oversight he paid a terrible price. ${ }^{49}$

Methuen's original plan was to leave a small force at Klokfontein to guard the British supply line along the railway, and to take the rest of his force in the direction of Jacobsdal, to the east, and from there to attack the Boer positions at Spytfontein (the ridges where his intelligence indicated the Boers would contest his advance) from their left flank and roll them up in a westerly direction. Methuen had learned from his experiences at Belmont and Graspan that the Boers preferred to defend entrenched positions on the koppies and therefore anticipated that the Boers would be waiting for him in the koppies and ridges of Spytfontein. ${ }^{50}$

On the evening of 27 November, a scouting party met such fierce resistance along the river that they reported that a large force of Boers occupied the area around the river. Due to the flat terrain, they could only penetrate to about two to three miles (about 3,2 to 4,83 kilometres) from the river and could not acquire any new information regarding the Boer positions, except to indicate that there was a larger Boer force than previously estimated. Methuen did not believe this, but reports from scouting parties sent out during the night, as well as those from friendly natives and loyalists who stayed in the vicinity of the river, all confirmed that a large Boer force occupied the river banks. This forced Methuen to change his plan, and he decided to clear the area of Boers first before returning to his original plan. He still believed that this was only a Boer outpost and that the main force waited at Spytfontein.

Methuen's new plan was to attack the Boers in the front and from the flanks. The railroad to Kimberley split the battlefield in two in the vicinity of the Modder River. To the east of the railroad, the attack initially went as planned. This provided 
credibility to Methuen's contention that the Boer positions were only manned by a small force, with the main force waiting at Spytfontein. ${ }^{51}$ The mounted troops rode ahead of the main force and were making good progress when they were met by fierce resistance at a distance of about 1500 paces. Major Little reported to Methuen that the area near the river was heavily defended by a large Boer force. Methuen ignored the report. For almost an hour the infantry marched forward as if on a parade ground.

The British march came to an abrupt halt at 08:00 when they were at 700 to 1200 paces from the Boer positions and the Boers opened fire. The Boers had orders to wait until the British were only 300 paces away before opening fire. The ill discipline of the Boers saved Methuen from total disaster as it averted the decimation of his force. ${ }^{52}$ However, Methuen still lost many soldiers, and his attack ground to a halt. The soldiers who tried to manoeuvre around the Boers' eastern flank came upon the steep banks of the swollen Riet River ${ }^{53}$ and were shot at from their right flank. This rendered the largest part of the force unable to counterattack. For the trapped British soldiers, a long and terrible ordeal had begun. With temperatures of $43^{\circ} \mathrm{C}\left(110^{\circ} \mathrm{F}\right)$ on the bare soil where the soldiers were exposed and trapped ${ }^{54}$ and up to $35^{\circ} \mathrm{C}\left(90^{\circ} \mathrm{F}\right)$ in the shade, ${ }^{55}$ it was the Scottish soldiers who bore the brunt of the suffering. The sun blistered their bare legs sticking out under their kilts, and this, coupled with the lack of water, forced some soldiers to try and crawl back towards the water carts. ${ }^{56}$ This brought the Boer snipers into play, and the Coldstream Guards especially lost many men in this way. This desperate situation lasted for more than ten hours. ${ }^{57}$ During the rest of the battle, the flat terrain on which they lay pinned down made any attempt at communication extremely difficult, as anyone moving on the battlefield was shot down, even at long distances. ${ }^{58}$

West of the railway line, the British fared better. After the initial surprise of the Boer attack, the British regrouped, and the reserve forces marched west behind a low ridge. They managed to progress unnoticed to about 2000 paces from the Modder River on the Boers' right flank. ${ }^{59}$

Opposite the small village of Rosmead, General Pole-Carew and his men were met with fierce resistance from Commandant Greyling of the Boer forces, who was entrenched behind a low hill and farmhouse, about 300 paces south of the Modder River. Pole-Carew realised that these Boers were guarding one of the few drifts where it was possible to cross the Modder River and that he had stumbled upon a situation that could offer him a foothold on the north bank. The terrain provided the key to accomplish this. A ditch ran from his position to the river bed of the Modder River - and the Boers had failed to occupy it. He immediately instructed 
his men to use the cover afforded by the ditch to attack Greyling. When a British cannon started to support Pole-Carew, Greyling and his men found themselves under attack from two sides, and Greyling ordered his men back over the river. By 13:00, Pole-Carew had secured the drift and his men had crossed the river, taken Rosmead, and had begun to roll up the Boer western flank. After this initial success, they were attacked by General De la Rey and forced back into Rosmead, where Pole-Carew and his men spent a restless night, waiting for daybreak. ${ }^{60}$

Although the Boers inflicted heavy casualties on the British, they decided to give up their position as General Cronje anticipated that the Boer forces would not be able to hold on to it the next day. ${ }^{61}$ Had the Boer forces kept their firing discipline and waited until the British troops were only 300 paces from the river, they could potentially have massacred the British and would not have had to retreat during that evening.

The terrain of the battlefield played an enormous part in the battle. The flat, almost featureless terrain on the eastern side of the railway line favoured the hidden Boer defenders in the beds of the Riet and Modder Rivers. The long distances over which scouting parties could be seen and engaged by Boer marksman made effective reconnaissance virtually impossible. ${ }^{62}$ This failure to reconnoitre the course of the Riet River accurately, together with the lack of adequate maps and the adroit use of the terrain by the Boers, led to the stalemate on the western flank. ${ }^{63}$

The British were trapped on the open veld under a burning African sun, without much cover or shade, shot at by a nearly invisible foe, and unable to manoeuvre to the east to attack the Boers' left flank because of the Riet River and their inability to find a fordable drift.

Ironically, it was also the terrain that saved the day for the British. The Boer generals failed to guard the drift on the British left flank adequately, the only place where the river could be crossed. It was here, at Rosmead, with the clever use of the ridge and donga, that General Pole-Carew foresaw a foothold on the north bank of the Modder River and seized the opportunity. The next morning, as the day broke over the battlefield, Methuen found the Boer trenches deserted and he could at last cross the river that he had reached 24 hours earlier.

The toll exacted by the clever use of the terrain resulted in the deaths of four British officers and 67 men, 19 officers (amongst them Methuen himself) and 370 men wounded, and 18 men reported missing in action. On the Boer side, estimates vary between 30 and 40 dead and wounded. 
From the Modder River, the Boers fell back to the Magersfontein koppies (hills), while Methuen was left to nurture his wounds, replenish his force and ponder the next battle on his way to relieve Kimberley. ${ }^{64}$

\section{From Modder River to Magersfontein and Paardeberg}

At the insistence of General Koos de la Rey, the Boers decided to take up defensive positions at a line of koppies called Magersfontein. ${ }^{65}$ This placed them directly in Methuen's way, as the latter had to pass directly by Magersfontein via the railway line in order to reach Kimberley. The Boers, having learnt from their mistakes at Graspan and Enslin, would stay out of the koppies this time around and dig their positions in front of the Magersfontein koppies rather than on the hilltops. ${ }^{66}$

On 9 and 10 December, the British shelled the Magersfontein koppies with their cannons. The effect on the Boers was insignificant ${ }^{67}$ as they were in concealed trenches at the base of the koppies. Only three Boer casualties were reported, none of which was fatal. ${ }^{68}$ After the two-day artillery barrage, the British infantry advanced on the Magersfontein koppies during the early morning hours of 11 December 1899. Shortly before dawn, the Boers started mowing down the tightlymassed columns of advancing British soldiers before the latter could open up their ranks. The Boer trenches were much closer to the British than the latter had expected. Consequently, the command to open up ranks into line formation was given to the British infantry too late. By the end of the battle, the British had lost 288 men with another 700 wounded and yet another 100 missing in action. The Boers had lost only 71 men, with another 184 wounded. Although Magersfontein was a significant tactical defeat for the British, the Boers did not follow up on their success. Instead, they expanded their defensive positions, giving the British the opportunity to build up a huge force at Modder River.

After Buller's defeat at Colenso, the British government decided to replace him as supreme commander with General (Lord) Frederick Sleigh Roberts. On 11 February 1900, Roberts launched his campaign from Modder River against Cronje, who was still dug in at Magersfontein. ${ }^{69}$

When French broke through the Boer lines and relieved Kimberley on 15 February, ${ }^{70}$ Cronje realised that he could be outflanked by Roberts, and he decided to retreat in the direction of Bloemfontein. ${ }^{71}$ Cronje was of the opinion that Roberts would move on Bloemfontein, the capital of the Orange Free State Boer republic, which lay south-east of Magersfontein. He believed that, with the help of reinforcements on their way from the Natal front, he could prevent Roberts from reaching Bloemfontein. Cronje's departure from Magersfontein was part of his tactics to tire the enemy by continually taking up defensive positions in front of 
them. From these positions he would attempt to inflict heavy casualties on the attacking British force while protecting his own vastly outnumbered Boer force.

During the evening of 15 February 1900, Cronje, with his force of around 5000 men and 400 ox waggons, retreated from Magersfontein. The British $6^{\text {th }}$ Division slept so well that evening that they did not notice the retreat until early on the morning of 16 February. Lord Kitchener, Chief of Staff of Lord Roberts, realised that Cronje planned to cross the Modder River to the south-east in order to curb the British advance on Bloemfontein. To halt, or at least slow Cronje down, Kitchener ordered the $13^{\text {th }}$ Brigade, along with Lieutenant Colonel Hannay's brigade, to immediately set after Cronje and impede his progress by attacking him from the rear. Kitchener had hoped to slow Cronje down sufficiently to allow the various British divisions that were spread out over a vast distance to amass and catch up. The fast-moving cavalry of the two British brigades soon caught up with Cronje and engaged his rear guard, which defended the slow-moving retreat defiantly throughout the day. ${ }^{72}$ By early evening of 16 February, Cronje had taken up a good defensive position on the northern bank of the Modder River at Klipkraaldrif, and nightfall suspended the hostilities. The heavy fighting during the day had severely tired both the two British brigades and Cronje's army. ${ }^{73}$

Cronje had to cross the Modder River from the northern bank to the southern bank in order to gain a position between Roberts and Bloemfontein. However, crossing the swollen Modder River with 400 ox waggons, pulled by very tired oxen, was a daunting task. Cronje was searching for a crossing that offered good defensive positions on both sides of the river. He believed that Koedoesdrif, approximately 20 kilometres north-east of his position at Klipkraaldrif, was where they could safely cross. He was also of the opinion that the terrain of the area around Koedoesdrif would enable his force to use the area as a defensive position that would keep Roberts from reaching Bloemfontein. Koedoesdrif is overlooked by a hill on the northern bank of the Modder River and a line of koppies, running in a south-southwesterly direction on the southern bank. Cronje knew that Roberts would have to pass Koedoesdrif, because the Modder River was the only source of water large enough to sustain his force on its march to Bloemfontein. Cronje therefore planned to use Koedoesrand and the koppies to its south as a defensive position.

Cronje was hoping that the two British brigades would be so tired from the day's fighting that they would not notice his departure for Koedoesdrif during the night of 16 February. His plan worked well. His force moved as fast as the oxen could pull the waggons and this created some space between him and his pursuers. Those oxen that could not keep up were left behind. The small group of women and children, around 275, as well as the rest of his marching army were exhausted. For a 
second night in a row they were not able to sleep, but had to continue the march. In addition, there was no time to eat properly as Cronje's force had been living on rusks and water during their retreat. At midnight on 16 February, Cronje ordered his force to rest at Paardebergdrif. ${ }^{74}$

\section{The Battle of Paardeberg (17-27 February 1900)}

After resting for four hours at Paardebergdrif, the Boers started trekking again in the direction of Koedoesdrif. By 08:00 on 17 February, the vanguard of the Boer force had reached Wolwekraal, around midway between Paardebergdrif and Koedoesdrif (see Figure 3). Cronje, who could now see Koedoesrand, gave the order to outspan, ${ }^{75}$ as he was of the opinion that he had put enough daylight between himself and the pursuing British force. He decided that his force should cross the Modder River at Vendusiedrif, about two kilometres west of Wolwekraal, and continue on the southern bank of the Modder River until they reached Koedoesdrif, which was now only eight kilometres to their east. Cronje was mistakenly under the impression that the small patrol he had sent to secure Koedoesrand during the evening of 16 February had done their duty and that Koedoesrand and Koedoesdrif were now under his control. The tired Boers made full use of the opportunity to rest by unyoking the oxen, slaughtering and roasting sheep, as well as cooking food. For most of the Boers, this was their first hot meal in days.

Cronje, however, was completely unaware of the movements of Major General French. French and his utterly exhausted cavalry division, who had just relieved Kimberly, received orders from Roberts at 10:00 on 16 February to start pursuing the retreating Cronje, ${ }^{76}$ who was about 50 kilometres east of Kimberley. French gathered his fatigued men and set off after Cronje with 1200 cavalrymen and 356 artillerists. By 10:15 on 17 February, French had reached Kameelfontein, about 10 kilometres north of the outspanned Boer force. French climbed a nearby hill and was pleased to see Cronje's force stretched out below him. The koppies at Kameelfontein are about 500 feet (approximately 152 meters) above the Modder River and provided French with an excellent view of Cronje's convoy. 
Cronje was so focused on inspanning that he did not notice French and his 12 cannon crossing the koppies at Kameelfontein. Unmolested, French brought his cannon into range, to the north of Cronje

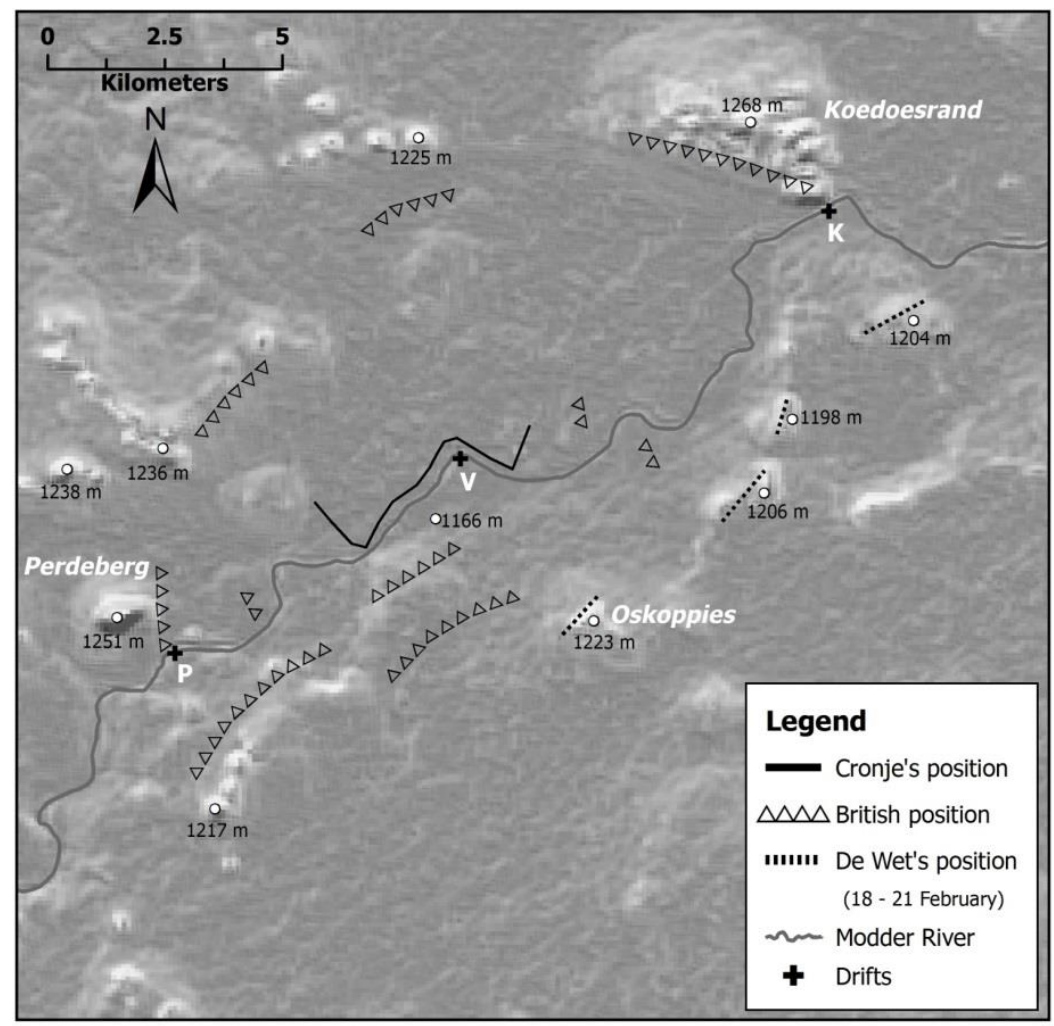

Figure 3: Battle of Paardeberg ${ }^{77}$

At 11:15, just as Cronje's first waggons were starting to cross the Modder river, French's cannons fired their first salvo on Vendusiedrif. This caused great panic in the Boer camp, driving them to run for cover in the river bed, and a large number of oxen and horses were killed during the barrage. Those animals that were not killed were scattered in all directions as their drivers deserted them in order to find cover. The loss of oxen made it nearly impossible for Cronje's convoy to move any further. 
Only those Boers on the western flank, under General Froneman, and those on the eastern flank under Commandant De Beer, did not seek cover in the river bed. The Boer artillery battery, under command of Major Albrecht, maintained their discipline and immediately answered French's artillery with four cannon. General Froneman, witnessing Major Albrecht's counterattack, started attacking the British western flank with his infantry. In the meantime, De Beer took Koedoesrand without any resistance. After seeing Froneman's attack of the British western flank, De Beer attacked the eastern flank and bombarded French's headquarters with a pom-pom, while his men pushed back the British $12^{\text {th }}$ Lancers, who had been sent to capture Koedoesrand. General French was in a precarious position. His men and horses were exhausted, he was being attacked in his centre by Albrecht's artillery, on his left by De Beer and on his right by Froneman, and was faced by a force nearly three times his own in numbers. However, the Boers did not push home for victory. ${ }^{78}$

The citizen Boer force was tired, hungry and demoralised and did not have the combat discipline of the professional soldiers they were fighting against. Despite the successes of Albrecht, Froneman and De Beer, Cronje could not motivate those Boers who were hiding in the river bed to reinforce the counteroffensive. The Boer force was unaware of the difficult position within which French found himself. If they had obeyed Cronje's commands to reinforce Albrecht, Froneman and De Beer, they could have pushed French back, settled in amongst the koppies around Koedoesrand and waited for Roberts' arrival from the west. Instead, without reinforcements, De Beer was forced to order his men to retreat to Koedoesrand as night fell on 17 February.

For the first time since his retreat started at Magersfontein, Cronje was in serious trouble. ${ }^{79}$ His convoy had become immobile due to the loss of oxen during the fight with French. By daybreak, French would again be able to attack from the north as soon as the sun allowed enough visibility. Cronje also knew that the day he had spent fighting French would have allowed Roberts to close in on him from the west. During the evening of 17 February, some of the officers serving under Cronje urged him to move the army to the southern bank of the Modder River. ${ }^{80}$ This would mean leaving behind the immobile laager that consisted of waggons, provisions, women and children. The Boer army could then take up defensive positions along the koppies to the south and wait for reinforcements from the Natal front. Cronje did not even consider their plan. He refused to separate the laager from the army. ${ }^{81}$

After a speedy reconnaissance of his position along the Modder River, Cronje was of the opinion that the river bed was a very good defensive position. At that stage, the bed of the Modder River was 60 metres wide and up to 12 metres deep at some points. Cronje felt that the river would provide sufficient cover for his 
people. $^{82}$ The broad, sloping banks of the Modder River were covered in bushes and trees that provided shelter and concealment. There were many dry gullies that ran perpendicular to the river, which provided natural trenches. Breytenbach states, "Dit het inderdaad gelyk na net so 'n goeie stelling as wat die Boere by Twee Riviere of by Magersfontein gehad het." (It indeed looked just as good a position as the Boers had at Twee Riviere [Battle of Modder River] and at Magersfontein. ${ }^{83}$ Cronje thought that he could hold out along the banks of the Modder at Vendusiedrif until Boer reinforcements arrived. However, unknown to Cronje, his position was in a shallow basin about 14 kilometres long and 10 kilometres wide. The koppies that surrounded his position would provide excellent artillery positions from where he could be attacked. Cronje ignored the terrain around his position to his peril.

At dawn on 18 February, Cronje, with just over 4000 men, lay waiting for the enemy. During the night, they had made use of the soft sandy soil to make dugouts for themselves. The women and children were placed in holes and caves in the high river bank. The convoy of waggons was still standing in plain sight of the British on the northern plain. ${ }^{84}$

Meanwhile, Roberts fell ill and stayed behind at Jacobsdal, some 20 kilometres south of Paardeberg. ${ }^{85}$ According to normal military custom, Lieutenant General Kelly-Kenny would have taken over command as the most senior of the divisional commanders. Roberts, however, effectively placed his chief of staff, General Kitchener, in command. He instructed all divisional commanders that he, Roberts, would convey his orders through Kitchener. The divisional commanders had no choice but to consider all commands from Kitchener as coming from Roberts himself.

Roberts, Kitchener and all the divisional commanders were agreed that they had to encircle Cronje to prevent him from escaping. However, they did not deliberate on how to approach Cronje after the encirclement, which proved to be a costly mistake. By the morning of 18 February, Roberts' main force, now effectively under the command of Kitchener, had caught up with Cronje. ${ }^{86}$

General Kelly-Kenny ordered his $6^{\text {th }}$ Division to capture the koppies around Cronje's position. His plan was to make use of artillery fire from the koppies to pound Cronje into submission until he surrendered. Kitchener, on the other hand, was certain that the Boers would capitulate if their position were to be stormed from all sides. He planned a simultaneous assault on Cronje's western and eastern flanks, combined with a frontal assault from the north, backed by artillery fire from the south. Kitchener was sure that the Boers would not be able to withstand such a massive onslaught. ${ }^{87}$ 
By 07:15 on 18 February, 38 British cannons, placed on dominating high ground both north and south of Cronje, were firing mercilessly at the Boer laager. Major Albrecht and his five cannons were no match for the superior firepower of the British artillery, and he ordered his cannons back into the river bed. This gave free play to the British artillery, which could now fire at will without any Boer pressure. The British artillery concentrated their fire on the ring of ox waggons that formed the Boer laager on the northern bank of the Modder River. The ox waggons formed the only clearly visible target, because all the Boers were concealed in the river bed. Kitchener, now aware of the fact that the Boers were positioned in the river bed, ordered his cannons to fire into the river bed itself. He was sure that the artillery fire had softened the Boers enough to allow for a frontal attack.

Kitchener ordered the $6^{\text {th }}$ Division to attack Vendusiedrif from the south. This meant that the British foot soldiers had to move over flat, open terrain with little or no cover, in broad daylight, against the Boer force that lay entrenched in the protective banks of the Modder River. ${ }^{88}$ The effect on the British lines was disastrous as the Boers mowed down the advancing troops. This episode typified the events that followed throughout the day. Time and again British soldiers were ordered to attack the Boer position from various fronts. ${ }^{89}$ On each occasion they were met with great resistance as they attacked a strong defensive position over the flat and open terrain directly surrounding the river. ${ }^{90}$ The British lost more soldiers on Sunday 18 February 1900 than on any other day during the war. The total casualty count on the British side was 1 270, with 303 men, including 13 officers, killed, 906 wounded (including 59 officers) and 61 (2 officers) taken captive. Generals Knox and Macdonald were among the wounded and Lieutenant Colonels Hannay and Aldworth among the dead. Casualty counts on the Boer side are not completely accurate. However, the Boer losses paled in comparison with those of the British. The total Boer casualty count was estimated at a mere 70 men. ${ }^{91}$

After reports of the massacre of 18 February, Roberts got up from his sickbed at Jacobsdal and rode hard for six hours to get to Paardeberg, where he took control of the British forces. ${ }^{92}$ In the meantime, Roberts had ordered all available troops to Paardeberg. He demanded Cronje's unconditional surrender, which the latter refused. At around 13:00 Roberts, now with 73 cannons, commenced an artillery barrage against Cronje's position. ${ }^{93}$ The artillery fire was kept going for the rest of the day and during the night of 19 February. Roberts used the cover of darkness and the artillery fire to inch his troops closer to the Boer lines. This was the general tactic ${ }^{94}$ he employed from 19 to 27 February. At 06:00 on 27 February 1900, Cronje surrendered. ${ }^{95}$ His force, severely pummelled by eight days of artillery fire from the commanding heights around their position, no longer had the will to fight. ${ }^{96}$ 
Roberts had amassed a force of 40000 with 100 cannons by the time Cronje capitulated. Cronje tried valiantly to hold out against this overwhelming force with approximately 4000 men and five cannons. Roberts' tactic of using the koppies around Cronje's position for artillery fire had worked. Not only did Cronje surrender, but Roberts' total casualty count for the eight-day period was only 132 , compared to the 1270 of 18 February. In total, the British casualty count for the Battle of Paardeberg was 1402 . For the same period, the total casualty count on Cronje's side was 414 with an additional 3919 men who surrendered on 27 February.

\section{Comparison of the battle terrains and their tactical utilisation}

The Battles of Modder River and Paardeberg share major characteristics regarding the terrain and its use. Let us start by highlighting their similarities. Firstly, both the Battles of Modder River and Paardeberg took place along the Modder River, some 45 kilometres and 81 days apart. At the first battle, the majority of the Boer force was entrenched in the Riet River, which lay just south of the Modder River. However, the Riet and Modder Rivers joined at that point, which afforded the Boers the opportunity to also entrench themselves along the banks of the latter, thereby gaining depth in defence, as their lines of deployment formed a wishbone structure. In terms of geologic structure, both battle terrains fall within the Palaeozoic Dwyka and Ecca groups, as part of the Karoo Supergroup, interspersed with intrusive dolerites that form the koppies. ${ }^{97}$ The Ecca group is characterised by dark shales, some sandstone layers and coal seams while the Dwyka group comprises mainly unsorted tillite and minor shale. ${ }^{98}$

Secondly, the river ran through a shallow basin with flat, near featureless terrain directly surrounding it. At both the Modder River and Paardeberg battle sites, the exceptionally flat terrain was an important distinguishing element of the area in which these battles were fought. This allowed the Boers, once entrenched in the banks of the river, to bring murderous fire onto the British attackers, who had to attack over a flat plain almost totally devoid of natural cover. The only natural cover at both battles was the scattered anthills that dotted the landscape. At both battles, the British learned that this made for an almost impregnable defensive position against infantry and cavalry attacks. Without high ground near the defensive position, it was even more difficult to engage the defenders of such a position with cannons, as it was extremely difficult to see the effect of the bombardment and to direct the firing of the cannon. The soft, alluvial soil of the river beds absorbed the effect of the British cannons, rendering the artillery fire less effective than when directed at an enemy entrenched in the rocky koppies which compounded the shrapnel effect. 
Thirdly, the vegetation on the flat terrain was sparse and consisted mainly of short grass and shrubbery that did not provide much cover for advancing forces. In the case of the Battle of Modder River, the Boers had enough time to clear the area in front of their position of vegetative obstructions.

Fourthly, the flat terrain surrounding the battlefields was interspersed with koppies. However, at Paardeberg the koppies were much closer to the Boer positions than at Modder River. Closer inspection of a topographic map of the area suggests that the closest koppies south of the Modder River were approximately 16 kilometres away. This distance was too big to render the high ground useful as an observation post for Methuen. At Paardeberg, this was not the case. The British forces had a clear view of Cronje's laager from the surrounding koppies. The koppies to the north of Cronje's position were between 1,5 and 10 kilometres away and between 44 and 160 metres higher than the river. The line of koppies to the south was between three and eight kilometres away and between 30 and 105 metres higher than the Boer position. From these koppies, the British could clearly see the course of the Modder River where they knew the Boers were hiding. It was this visibility, afforded by the local terrain, that enabled Roberts to keep Cronje pinned down in the river bed. In addition to the koppies being close enough to be used as observation and firing posts, the spatial arrangement of the koppies meant that Cronje could be encircled from the high ground all around his position. He was in the centre of a basin.

The two battles also shared similarities in the use of the terrain. Firstly, at both battles, the Boers entrenched themselves in the river bed. The wide bed itself provided excellent cover for the Boer army in the form of a natural trench. The soft soils of the river banks made it easy for the Boers to dig in and create shelters for themselves, while the flat terrain surrounding the river provided excellent advantage over advancing soldiers. The big difference between the two battles is the fact that, at Modder River, the Boers could withdraw from their entrenched positions at will, and slip away when the tide turned against them. This they did, when, under the cover of darkness, the Boers slipped away to Magersfontein to prepare for their next battle. At Paardeberg, once Cronje was encircled, withdrawal was no longer an option.

Secondly, the British used the flat areas around the river for unsuccessful frontal infantry and cavalry attacks during both battles. Methuen lost 478 of his force during one day's battle at Modder River while Kitchener lost 1270 at Paardeberg, also in one day. Both Methuen and Kitchener ignored the effect of the terrain in their attacks. Frontal infantry and cavalry attacks over flat plains against an enemy concealed in trenches cost the British dearly. The British victory at Modder 
River was the result of the Boers not taking full advantage of the terrain. They neglected to defend the only point, west of the railway line, where the British could cross the fast-flowing Modder River properly. Had the Boers defended the shallower crossing, Methuen would not have been able to cross the river and pose a significant threat to the Boers' western flank. At Paardeberg, victory for the British came only after they had used the tactical advantage afforded to them by the koppies around Cronje's laager. Their change in tactics from frontal infantry and cavalry assault to artillery barrage from the surrounding heights, supported by the slow tightening of the infantry noose around the Boer positions, resulted in their outright victory at a significantly lower cost than during the frontal attacks on 18 February 1900.

Ironically, at Paardeberg, once Cronje was encircled, the flat terrain he used to his advantage on 17 February became a trap. If he now wanted to break out of the British circle, he had to attack over the same flat terrain. The fact that most of his horses had been killed by the British artillery bombardment made this all the more difficult.

\section{Conclusion}

At Modder River, the Boers, under the command of Cronje, used the terrain to their advantage. The deep bed of the Modder River afforded good shelter for Boer troops while the exceedingly flat terrain over which the British had to attack formed an ideal killing zone for the Boer ambush. The nearest high ground was too far away from the Modder and Riet Rivers to aid Methuen in his reconnaissance of the Boer positions. The flat plain, almost totally devoid of vegetation, offered little cover to the British soldiers. They were fighting a nearly invisible foe from a tactically perilous position. Trying to outflank the Boers by moving eastwards, the British soldiers were foiled by the swollen Riet River. Geography gave the British the key to the battle. The donga and ridge used by General Pole-Carew to get his soldiers to the banks of the Modder River and the drift opposite Rosmead, allowed the British to establish a foothold on the north bank of the river. Cronje then concluded that the Boers would not be able to repel another British attack and he withdrew his troops to Magersfontein.

Cronje was outdone by terrain at Paardeberg. Although he used the terrain of the river bed and surrounding plains to his advantage, he ignored the importance of the koppies all around him. While the deep bed of the Modder River, the flat terrain, the virtual absence of vegetation, and the scant cover on the battlefield of Modder River were replicated at Paardeberg, the situation regarding the koppies was different. At a distance of 16 kilometres from the Boer positions at the Modder River battlefield, the koppies proved worthless for observation, thus Methuen was unaware 
of the exact Boer positions. Even when he found out that the Boers were holding a strong position in the river, he was unable to use the koppies to direct his artillery fire. At Paardeberg, General French could easily ascertain the exact position of the Boers from one of the nearby koppies. British cannon fire could also be directed from these koppies during the attacks on Cronje's positions. Once encircled by 100 cannons from the nearby koppies that provided good firing and observation posts, Cronje was doomed.

\section{Endnotes}

${ }^{1}$ During the research for this article, inconsistencies in the use of the concepts 'terrain' and 'topography' were discovered. According to various geographical and geomorphological definitions, the term 'topography' refers to the surface features of an area and includes landforms, as well as other aspects, both of natural and human origin. (Monkhouse, FJ \& Small, J (eds). A dictionary of the natural environment. London: Edward Arnold, 1978, 297-298; Monkhouse, FJ, Steyn, JN \& Boshoff, LP (eds). A dictionary of geography: Southern African edition. Pretoria: De Jager HAUM, 1993, 337; Small, J \& Witherick, M (eds). A modern dictionary of geography. London: Edward Arnold, 1995, 245). 'Terrain', on the other hand, is defined as " $[\mathrm{t}] \mathrm{he}$ physical character of an area, its configuration" (Monkhouse \& Small op. cit., p. 292; Monkhouse et al. op. cit., p. 331). However, when they refer to 'terrain analysis', Galgano and Palka define it as "the collection, interpretation, and geographic analysis of the natural and man-made features of an area to predict the effect of the terrain on military operations" (Galgano, FA \& Palka, EJ (eds). Modern military geography. New York: Routledge, 2011, 415.) For clarity's sake, in this paper the term 'terrain' was taken to mean the natural and man-made features of the area under discussion.

${ }^{2}$ Some authors also use a different spelling, namely Perdeberg.

${ }^{3}$ Galgano \& Palka op. cit., p. xii.

${ }^{4}$ Blond G. La Grande Armée. London: Arms and Armour Press, 1995; Winters, HA, Galloway, GE Jr, Reynolds, WJ \& Rhyne, DW. Battling the elements: Weather and terrain in the conduct of war. Baltimore: John Hopkins University Press, 1998.

5 Ackermann, PCM. "Aardrykskundige invloede in die stryd tussen Brittanje en die Boere Republieke met besondere verwysing na die Tweede Vryheidsoorlog". Doctoral dissertation. University of South Africa, 1957.

${ }^{6}$ Puckett, RM. "The Rapido river crossings". Military Review 74/1. 1994. 73. 
${ }^{7}$ Gray, CS. "Inescapable geography”. In Gray, CS \& Sloan, G (eds), The journal of strategic studies: Special issue on geopolitics, geography and strategy 22(2/3). 1999. 161-177.

${ }^{8}$ Palka, EJ, Galgano, FA \& Corson, MW. “Operation Iraqi Freedom: A military geographical perspective”. The Geographical Review 96/3. 2005. 373-399.

${ }^{9}$ Palka, EJ. "Operation Enduring Freedom and the military geographic challenges of Afghanistan". In Palka, EJ \& Galgano, FA (eds), Military geography: From peace to war, New York: McGraw-Hill, 2005, 321-342.

${ }^{10}$ Häusler, H. "Historic maps of terrain evaluation”. In Mang, R \& Häusler, H. (eds), International handbook military geography, , Vienna: Arbeidsgemeinschaft Truppendienst, Ministry of Defence, 2006, 257-271.

11 Schroeder, KA. "Mountainous terrain and the Prussian invasions of Bohemia in 1757 and 1866". In Häusler, H \& Mang, R (eds), International handbook military geography, Vol. 2, Vienna: Arbeidsgemeinschaft Truppendienst, Ministry of Defence, 2011, 484-493.

12 Gnaser, G. "Warfare in mountainous regions: The last days of the Second World War in the Semmering area". In Häusler \& Mang op. cit., pp. 226-235.

${ }^{13}$ Galgano, FA. "Streams and military landscape". In Galgano \& Palka op. cit., pp. $109-123$.

${ }^{14}$ Galgano, FA. "The geography of amphibious warfare”. In Galgano \& Palka op. cit., pp. 184-200.

${ }^{15}$ Winters et al. op. cit.

${ }^{16}$ Collins, JM. Military geography for professionals and the public. Washington, DC: National Defense University Press, 1998.

${ }^{17}$ Galgano \& Palka op. cit.

${ }^{18}$ Metzger, TL. "Terrain analysis for Desert Storm". Engineer 22/1. 1992. 25.

${ }^{19}$ Doyle, P \& Bennett, MR. "Military geography: Terrain evaluation and the British Western Front 1914-1918”. The Geographical Journal 163/1. March 1997. $1-24$.

${ }^{20}$ Doyle, P \& Bennett, MR. "Military geography: The influence of terrain in the outcome of the Gallipoli Campaign, 1915". The Geographical Journal 165/1. March 1999. 12-36.

21 Tate, J. "Terrain analysis for decision making”. In Mang \& Häusler op. cit., pp. 321-333.

22 Kimble, S \& O'Sullivan, P. "Terrain and guerrilla warfare in Navarre, 18081814". In Doyle, P \& Bennett, MW (eds), Fields of battle: Terrain in military history, Dordrecht: Springer, 2002, 51-62. 
${ }^{23}$ Ehlen, J \& Abrahart, R. "Effective use of terrain and tactics in the American Civil War: The Battle of Fredericksburg, December 1862”. In Doyle \& Bennett, Fields of battle ... op. cit., pp. 63-97.

24 Doyle, P. "Terrain evaluation of the Hannibalic Alpine Invasion Route". In Häusler \& Mang op. cit., pp. 344-355.

${ }^{25}$ Smit, HAP. "Methuen's Northern Cape Campaign, Anglo Boer War, 1899-1902”. In Galgano \& Palka op. cit., pp. 494-502.

${ }^{26}$ Dye, M. "Spioenkop: A case study of the potential of modern mapping techniques to enhance understanding of historical battles". Paper delivered at the 2012 GISSA conference, Johannesburg, 2-4 October 2012.

${ }^{27}$ Royal Commission. Report of His Majesty's Commissioners Appointed to Inquire into the Military Preparations and other Matters connected with the War in South Africa. London: His Majesty's Stationery Office, 1903; Muller, CFJ. Vyfhonderd jaar Suid-Afrikaanse geskiedenis. Pretoria: Academica, 1977.

${ }^{28}$ Farwell, B. The Great Boer War. London: Wordsworth, 1999, 46-47.

29 Wessels, A. Die Anglo-Boereoorlog, 1899-1902: 'n Oorsig van die militêre verloop van die stryd. Bloemfontein: Oorlogsmuseum van die Boererepublieke, 1991, 9.

${ }^{30}$ Pakenham, T. The Boer War. London: Weidenfeld and Nicolson, 1979, 158-163.

${ }^{31}$ Wessels op. cit., pp. 9-10.

${ }^{32}$ Farwell op. cit., pp. 90-91.

${ }^{33}$ Wessels op. cit., p. 15.

${ }^{34}$ Breytenbach, JH. Die geskiedenis van die Tweede Vryheidsoorlog in Suid-Afrika, 1899-1902, Deel 2. Pretoria: Government Printers, 1971, 5.

${ }^{35}$ Wessels op. cit., p. 16.

${ }^{36}$ Amery, LS. The Times history of the war in South Africa, 1899-1902 (Vol. II). London: S. Low, Marston, 1902, 333-340; Breytenbach op. cit., p. 45.

${ }^{37}$ Farwell op. cit., pp. 97-98.

${ }^{38}$ Amery op. cit., pp. 341-342.

${ }^{39}$ Wessels op. cit., p. 16.

${ }^{40}$ Amery op. cit., p. 344.

${ }^{41}$ Pakenham op. cit., p. 193.

${ }^{42}$ Breytenbach op. cit., p. 59.

43 Doyle, AC. The Great Boer War: A two years' record, 1899-1901. London: McClure, Phillips, 1901, 141-142.

${ }^{44}$ Breytenbach op. cit., p. 61. 
${ }^{45}$ Reuter HI, Nelson, A \& Jarvis, A. "An evaluation of void filling interpolation methods for SRTM data". International Journal of Geographic Information Science 21/9. 2007. 983-1008.

46 The pom-pom was a Maxim-Nordenfelt cannon of $37 \mathrm{~mm}$ calibre. The name referred to the sound it made when fired (Breytenbach, JH. Die geskiedenis van die Tweede Vryheidsoorlog in Suid-Afrika, 1899-1902, Deel 1. Pretoria: Government Printers, 1969, 155).

47 Amery op. cit., p. 344.

${ }^{48}$ Pakenham op. cit., p. 189.

${ }^{49}$ Breytenbach, Deel 2 op. cit., p. 65.

${ }^{50}$ Farwell op. cit., p. 97.

${ }^{51}$ Breytenbach, Deel 2 op. cit., p. 63.

${ }^{52}$ Pakenham op. cit., p. 195.

53 Ackermann op. cit.; Maurice, F. History of the war in South Africa, 1899-1902. London: Hurst and Blackett, 1906, 249-251.

${ }^{54}$ Breytenbach, Deel 2 op. cit., p. 72.

${ }^{55}$ Pakenham op. cit., p. 196.

${ }^{56}$ Creswicke, L. South Africa and the Transvaal War. Edinburgh: TC \& EC Jack, $1900,99$.

57 Colville, HE. The work of the Ninth Division in South Africa, 1900. London: Edward Arnold, 1901, 11.

${ }^{58}$ Amery op. cit., p. 352.

${ }^{59}$ Breytenbach, Deel 2 op. cit., p. 74.

${ }^{60}$ Ibid., p. 81.

${ }^{61}$ Wessels op. cit., p. 16.

${ }^{62}$ Waters, WHH. The war in South Africa. London: John Murray, 1904, 83.

${ }^{63}$ Breytenbach, Deel 2 op. cit., p. 95.

${ }^{64}$ Davitt 1902, The Boer fight for freedom (1st ed.). New York \& London: Funk \& Wagnalls, $211-212$.

${ }^{65}$ Conradie, FD. Met Cronje aan die Wesfront. Cape Town: Nasionale Pers, 1943, 59.

${ }^{66}$ Maurice op. cit., p. 307.

${ }^{67}$ Davitt op. cit., p. 214.

${ }^{68}$ Amery op. cit., p. 394.

${ }^{69}$ Wessels op. cit., p. 25.

${ }^{70}$ Scholtz, L. Why the Boers lost the war. New York: Palgrave Macmillan, 2005, 63.

${ }^{71}$ Mahan, AT. The story of the war in South Africa, 1899-1900, London: S Low, Marston, 1901, 275-276. 
72 Amery, LS. The Times history of the war in South Africa, 1899-1902 (Vol. III). London: S. Low, Marston, 1905.

${ }^{73}$ Breytenbach, JH. Die geskiedenis van die Tweede Vryheidsoorlog in Suid-Afrika, 1899-1902, Deel IV. Pretoria: Protea Boekhuis, 1983, 250-266.

${ }^{74}$ Ibid., pp. 266-268.

75 The term 'outspan' literally means to unyoke the oxen so that they can be fed and rest. In a more general sense it can also mean to relax. In this sense it probably meant both.

${ }^{76}$ Farwell op. cit., pp. 205-206.

${ }^{77}$ Reuter et al. op. cit., pp. 983-1008.

${ }^{78}$ Breytenbach, Deel IV op. cit., pp. 279-284.

${ }^{79}$ Waters op. cit., pp. 166-169.

${ }^{80}$ Breytenbach, Deel IV op. cit., p. 283.

${ }^{81}$ Although the human aspects of the battle fall outside the scope of this paper, it is worth reflecting on this decision by Cronje. At this stage of the war, the Boer army was a truly citizen army. To Cronje, leaving his waggons and the women and children was unthinkable. A professional soldier would perhaps have decided differently. Although General De Wet temporarily opened a back door for him when, on the $18^{\text {th }}$ he occupied and held positions to the south of Cronje's position, by that time the Modder River was in flood, and he would have struggled to cross. Even more importantly, De Wet could not guarantee a safe passage to Cronje, as some British troops were stationed between him and the river (Breytenbach, Deel IV op. cit., p. 350.)

${ }^{82}$ Waters op. cit., p. 179.

${ }^{83}$ Breytenbach, Deel IV op. cit., p. 283.

${ }^{84}$ Colville op. cit., p. 34.; Kruger, R. Good-bye Dolly Gray: The story of the Boer War. London: Cassell, 1959, 235.

${ }^{85}$ Pakenham op. cit., p. 333.

${ }^{86}$ Breytenbach, Deel IV op. cit., p. 292.

${ }^{87}$ Waters op. cit., pp. 182-188.

${ }^{88}$ Doyle, The Great Boer War ... op. cit., p. 330.

${ }^{89}$ Colville op. cit., pp. 36-40.

${ }^{90}$ Sibbald, R. The war correspondents: The Boer War. Johannesburg: Jonathan Ball, 1993, 160-162.

${ }^{91}$ Wessels op. cit., p. 26.

92 Cunliffe, FHE. The history of the Boer War to the occupation of Bloemfontein. London: Methuen, 1904, 432.

${ }^{93}$ Doyle, The Great Boer War ... op. cit., pp. 334-335. 
94 De Wet, CR. Three years' war (October 1899-June 1902). Westminster: Archibald Constable, 1902, 55.

95 Waters op. cit., p. 209

${ }^{96}$ Farwell op. cit., p. 212.

97 Erikson, P. "The geological template". In Fox, R \& Rowntree, K (eds), The geography of South Africa in a changing world, Cape Town: Oxford University Press, 2000, 277-278; Vorster, CJ. "Simplified geology of South Africa, Lesotho and Swaziland". Pretoria: Council for Geoscience, 2003, 1.

98 Norman, N \& Whitfield, G. Geological journeys: A traveller's guide to South Africa's rocks and landforms. Cape Town: Struik, 2006. 